\title{
ЭКОЛОГО-ГЕОДИНАМИЧЕСКАЯ ХАРАКТЕРИСТИКА ТЕРРИТОРИИ ЦЕНТРАЛЬНО-ЧЕРНОЗЕМНОГО РЕГИОНА
}

\author{
Т. В. Овчинникова ${ }^{1}$, И. И. Косинова ${ }^{2}$, В. М. Смольянинов ${ }^{3}$, А. Н. Галкин ${ }^{4}$, Т. В. Ашихмина ${ }^{1}$ \\ ${ }^{1}$ Воронежский государственный технический университет \\ ${ }^{2}$ Воронежский государственный университет \\ ${ }^{3}$ Воронежский государственный педагогический университет \\ ${ }^{4}$ Витебский государственный университет
}

Поступила в редакцию 13 августа 2019 г.

\begin{abstract}
Аннотация: Проведена идентификация опасных эколого-геодинамических факторов в пределах Центрально-Черноземного региона, их ранжсиование по масштабу и интенсивности проявления. Осуществлено дифференцирование территории региона по интенсивности опасных экзогенных процессов, способствующих возникновению кризисных экологических ситуаџий. Выявлено, что максимальное количество природных опасностей локального уровня преобладает в Орловской и Тамбовской областях, муниципального - в Воронежской, Липеикой, Тамбовской и Белгородской, межмуниципального - в Курской, Липеикой и Воронежской. Проведенные исследования служат базой для разработки и реализации стратегий и мер рационального природопользования территории Центрально-Черноземного региона.
\end{abstract}

Ключевые слова: Экзогенные процессы, экологические ситуачии, регион, опасные факторы,экология, геодинамика, районирование территории.

\section{ECOLOGICAL AND GEODYNAMIC CHARACTERISTICS OF THE TERRITORY OF CENTRAL BLACK EARTH REGION}

\begin{abstract}
Central Black Earth region, their ranking on the scale and intensity of the symptoms. Implemented differentiation within the region by the intensity of dangerous exogenic processes, contributing to crisis ecological situations. It is revealed, that the maximum number of natural hazards local level prevails in Oryol and Tambov regions, municipal - in the Voronezh, Lipetsk, Tambov and Belgorod, intermunicipal - Kursk, Lipetsk and Voronezh. Conducted research serve as a basis for development and implementation of strategies and remedy rational nature management of Central Black Earth region.
\end{abstract}

Keywords: exogenous processes, environmental situation, region, hazards, environmental Geodynamics, zoning of the territory.

\section{Введение}

Современный этап развития цивилизации характеризуется значительным ростом антропогенной нагрузки на окружающую природную среду, следствием которой является увеличение частоты и интенсивности стихийных бедствий и техногенных чрезвычайных ситуаций. Проявление последствий названных процессов уже давно вышло за рамки отдельно взятых государств, поэтому решение проблемы экологической безопасности требует согласованных действий всего мирового сообщества [1].

Так, Хиогская рамочная программа действий, принятая правительствами 168 стран на 2005-2015 гг., создала потенциал реализации Международной стра- тегии уменьшения опасности бедствий (МСУОБ), которая включает все меры, направленные на недопущение или ограничение негативных последствий опасных природных явлений, и связанных с ними экологических и техногенных катастроф. МСУОБ осуществляется на межсекторальной и междисциплинарной основе и является международной программой по уменьшению опасности бедствий [2].

Общая идея МСУОБ (международная стратегия уменьшения опасностей бедствий) включает разработку и реализацию стратегий и мер управления риском на всех уровнях с учетом особых потребностей населения, городских агломераций и сельскохозяйственных секторов. 
Целью настоящего исследования является экологогеодинамическая характеристика территории Центрально-Черноземного региона для разработки структуры рационального природопользования и обеспечения комфортности жизнедеятельности населения.

Основные задачи исследования:

- идентификация опасных эколого-геодинамических факторов в пределах Центрально-Черноземного региона, их ранжирование по масштабу и интенсивности проявления;

- установление характера и видов возможных опасных эколого-геодинамических проявлений для дальнейшей разработки стратегии предупреждения кризисных экологических ситуаций в регионе с интенсивной антропогенной нагрузкой на природную среду;

- эколого-геодинамическое дифференцирование территории региона по интенсивности опасных экзогенных процессов, способствующих возникновению кризисных экологических ситуаций.

\section{Объект и методы исследования}

Район исследований находится в южной части Центральной России и имеет внутриконтинентальное географическое положение. В состав Центрально-Черноземного региона входят: Белгородская, Воронежская, Курская, Липецкая, Орловская и Тамбовская области. Его общая площадь составляет 192,4 тыс. км² [3].

Район имеет индустриально-аграрную экономическую специализацию, представленную машиностроительной, горнорудной, металлургической, химической и пищевой промышленностью. Аграрный сектор специализируется на производстве зерна, технических культур и животноводческой продукции [4].

Климат Центрально-Черноземного региона уме-

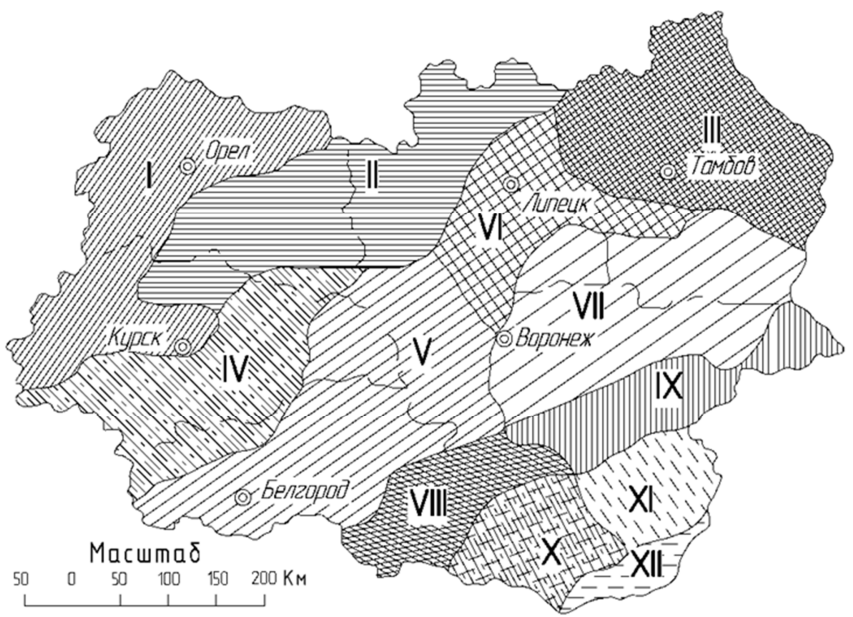

Результаты исследований и их обсуждение

Изучение проявления возможных кризисных экологических ситуаций природного характера в Центрально-Черноземном регионе позволяет отнести их к типу «непреднамеренные», классу «природные» и выделить подклассы: литосферные, атмосферные, гидросферные, включающие в себя группы и виды ренно-континентальный, рельеф представлен Среднерусской и Калачской возвышенностями, располагающимися на западе и юго-востоке, и Окско-Донской низменностью - на востоке. Возвышенности имеют частое и глубокое расчленение, водоразделы залегают на абсолютных отметках 200-250 м, абсолютные отметки низменности не превышают 150-180 м, рельеф плоский, слабо изрезан балками и оврагами [5].

Необходимо отметить значительное влияние рельефа на распределение атмосферных осадков и формирование почвенно-растительного покрова. Генетические связи почвенного покрова с рельефом и климатическими особенностями отражены в почвенноклиматическом районировании Центрально-Черноземного региона (рис. 1) [6].

В характеризуемом районе отмечается значительная антропогенная нагрузка на природную среду и, соответственно, высокая экологическая напряженность [7, 8]. Эколого-геодинамическая характеристика территории ЦЧР производилась нами на основе бассейнового подхода, позволяющего рассматривать бассейны рек одновременно как естественные природные ячейки экогеосферы, в которых происходит формирование водных и земельных ресурсов, и как природно-хозяйственные системы, контурами которых следует считать границы водосборов малых и средних рек $[9,10]$.

При эколого-геодинамической характеристике района исследований использовались следующие данные: тектонические особенности территории, характер и свойства рельефообразующих пород, геоморфологические условия, водный режим территории, наличие экзогенных процессов, использование земель в хозяйственной деятельности человека.

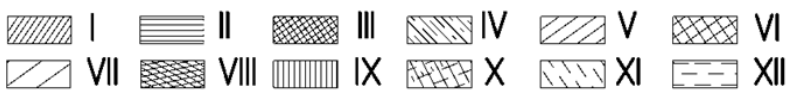

Puc. 1. Почвенно-климатические районы ЦЧР [6]. Условные обозначения: $I$ - серые лесные и оподзоленные черноземы; II - выщелоченные черноземы; III - выщелоченные черноземы; $I V$ - слабовыщелоченные типичные и выщелоченные; $V$ - типичные среднемощные и выщелоченные черноземы; $V I-$ типичные среднемощные и выщелоченные; VII - типичные мощные и среднемощные; VIII - обыкновенные; $I X$ - обыкновенные; $X$ - обыкновенные; $X I$ обыкновенные; XII - обыкновенные маломощные и южные черноземы.

кризисных экологических ситуаций. По масштабу природные опасности подразделяются на уровни: локальный, муниципальный, межмуниципальный, региональный, межрегиональный, федеральный (табл. 1).

К эколого-геодинамическим факторам формирования экологической ситуации в Центрально- Черноземном регионе относятся: овражная эрозия, оползни, 
Природные опасности в Центрально-Черноземных областях

\begin{tabular}{|c|c|c|c|c|c|c|c|c|c|c|c|}
\hline \multirow{2}{*}{ 息窝 } & \multirow[b]{2}{*}{ 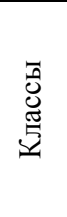 } & \multirow[b]{2}{*}{ 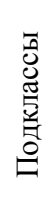 } & & \multirow[b]{2}{*}{ Вид } & \multicolumn{7}{|c|}{ Уровень опасности } \\
\hline & & & & & 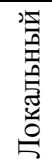 & 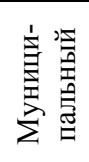 & 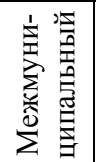 & 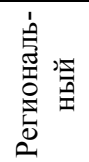 & 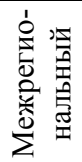 & 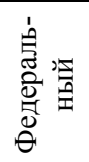 & 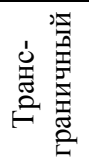 \\
\hline \multirow{22}{*}{ 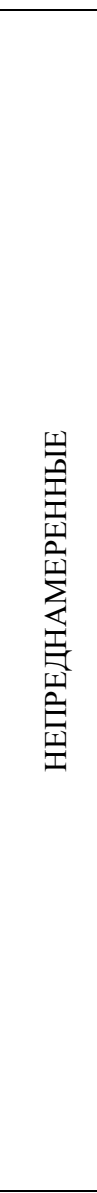 } & \multirow{22}{*}{ 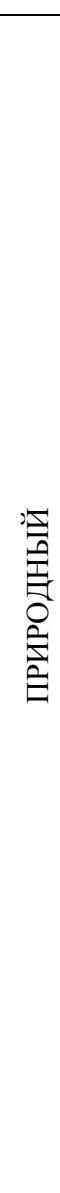 } & \multirow{7}{*}{ 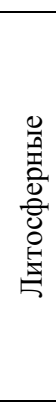 } & $\begin{array}{c}\text { Эндо- } \\
\text { ген- } \\
\text { ные }\end{array}$ & Землетрясение & & & & & & & \\
\hline & & & \multirow{6}{*}{ 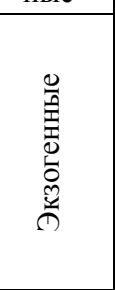 } & Овражная эрозия & & & & & & & \\
\hline & & & & Оползни & & & & & & & \\
\hline & & & & Карстовые провалы & & & & & & & \\
\hline & & & & Просадка грунтов & & & & & & & \\
\hline & & & & Переработка берегов & & & & & & & \\
\hline & & & & Заиление & & & & & & & \\
\hline & & \multirow{12}{*}{ 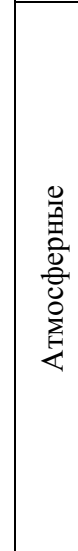 } & \multirow{12}{*}{ 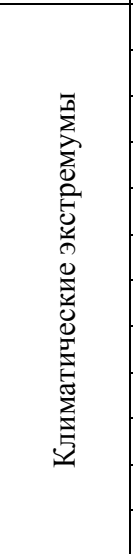 } & Высокие температуры & & & & & & & \\
\hline & & & & Низкие температуры & & & & & & & \\
\hline & & & & Сильные дожди & & & & & & & \\
\hline & & & & Градобития (грозы) & & & & & & & \\
\hline & & & & Снегопады & & & & & & & \\
\hline & & & & Гололед и изморозь & & & & & & & \\
\hline & & & & Метели & & & & & & & \\
\hline & & & & Ветры(пыльные бури) & & & & & & & \\
\hline & & & & Снегоотложение & & & & & & & \\
\hline & & & & Туманы & & & & & & & \\
\hline & & & & Засуха & & & & & & & \\
\hline & & & & Вымерзание & & & & & & & \\
\hline & & 尊 & 芯 & $\begin{array}{l}\text { Наводнение в период } \\
\text { весеннего половодья }\end{array}$ & & & & & & & \\
\hline & & $\begin{array}{l}0 \\
\text { क्षे } \\
0 \\
0\end{array}$ & $\begin{array}{l}5 \\
0 \\
0 \\
0 \\
\\
\end{array}$ & Маловодье, пересыхание рек & & & & & & & \\
\hline & & 緟 & 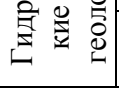 & $\begin{array}{l}\text { Изменения уровней } \\
\text { грунтовых вод }\end{array}$ & & & & & & & \\
\hline
\end{tabular}

- опасности

Примечание: в классификации ЧС - трансграничных на сегодняшний день нет (упразднили).

карстовые провалы, просадка грунтов, переработка берегов водохранилищ, заиливание русел рек.

Анализ Центрально-Черноземного региона по условиям развития эколого-геодинамических факторов позволил сгруппировать их в 10 районов (рис. 2). В основу выделения каждого района положена информация по литологическому составу рельефообразующих пород, густоте балочного расчленения территории, облесенности и распаханности земель, водопроницаемости, величине увлажнения, глубине местного базиса эрозии (табл. 2).

Рельефообразующие породы представлены широким возрастным спектром - от девонских до современных. Среди них: карбонатная серия -известняки, мела и мергели, а также пески, суглинки и глины. По анализируемым критериям имеет место дифференциация показателей по выделенным районам. Коэффи- циент увлажнения изменяется от 0,8 до 1,3. Глубина базиса эрозии ориентирована на тектонические особенности территории, наиболее высокие значения характерны для Среднерусской и Калачской возвышенностей. Максимальная густота долинно-балочного расчленения приурочена к пескам и глинам мелового возраста, известнякам верхнего девона.

Показатели облесенности значительно изменяются по территории Центрально-Черноземного региона. В целом, площади, занятые лесами, незначительны и варьирую от 5 до 14 \%. Данный показатель относится к группе экологических и во многом определяет эколого-геодинамическую характеристику региона в целом. Распаханность земель в регионе высокая и составляет от 55 до 68 \%. Максимально распаханы земли в Курской и Орловской областях.

Литологические особенности рельефообразующих 


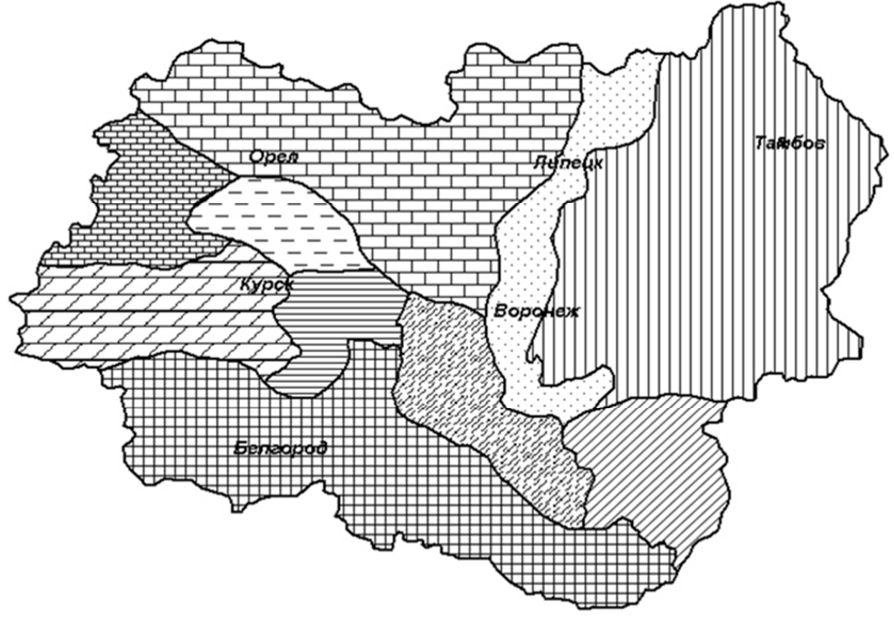

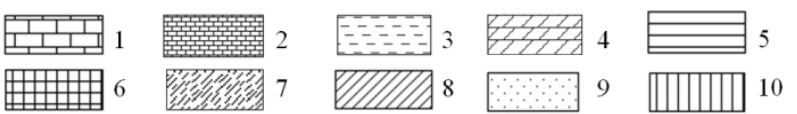

Рис. 2. Схема дифференциации районов Центральночерноземного региона по комплексу экологогеодинамических показателей. Районы: 1 - северный; 2 северо-западный; 3 - верховье рек Оки и Сосны; 4 - западный; 5 - центральный; 6 - южный; 7 - центральный (правобережье Дона); 8 - юго-восточный; 9 - район песчаных террас Дона и Воронежа; 10 - северо-восточный.

Таблица 2

Природные и техногенные факторы, формирующие эколого-геодинамическую характеристику ЦЧР

\begin{tabular}{|c|l|c|c|c|c|c|}
\hline Район & \multicolumn{1}{|c|}{ Рельефообразующие породы } & $\Phi_{2}$ & $\Phi_{3}$ & $\Phi_{4}$ & $\Phi_{5}$ & $\Phi_{6}$ \\
\hline I & Известняки верхнего девона & 1,3 & 132 & 1,2 & 8,8 & 61 \\
\hline II & Пески, глины мелового возраста & 1,3 & 122 & 1,6 & 8,0 & 59 \\
\hline III & Пески, глины мелового возраста & 1,2 & 120 & 0,9 & 9,0 & 62,2 \\
\hline IV & Мергели верхнемелового возраста & 1,2 & 107 & 0,8 & 10,0 & 68,0 \\
\hline V & Мергели верхнемелового возраста & 1,1 & 116 & 1,0 & 5,2 & 61 \\
\hline VI & Мела и мергели верхнемелового возраста & 0,9 & 140 & 1,0 & 9,6 & 60 \\
\hline VII & Четвертичные суглинки, мела верхнемелового возраста & 1,0 & 149 & 0,7 & 9,2 & 61 \\
\hline VIII & Четвертичные суглинки, мела верхнемелового возраста & 1,0 & 147 & 0,5 & 10,1 & 55 \\
\hline IX & Четвертичные аллювиальные пески & 1,0 & 108 & 0,5 & 10 & 54,2 \\
\hline X & Ледниковые четвертичные суглинки & 0,8 & 92 & 0,5 & 14,1 & 57 \\
\hline
\end{tabular}

Примечание: $\Phi_{2}$ - коэффициент увлажнения; $\Phi_{3}$ - глубина базиса эрозии, м; $\Phi_{4}$ - густота долинно-балочного расчленения, км/км ${ }^{2} ; \Phi_{5}$ - облесенность территории, \%; $\Phi_{6}-$ распаханность земель, \%.

пород определяют форму балок и оврагов, густоту расчленения, форму склонов, размеры водосборов.

Характер и интенсивность эколого-геодинамических процессов на водосборах рек ЦЧР показаны в табл. 3.

Среди опасных природных процессов ЦентральноЧерноземного региона наиболее масштабным и значимым является овражная эрозия. Факторами развития этого процесса, являются:

- климатические условия формирования весеннего стока с коротким периодом снеготаяния, когда до 70 \% этого стока скатывается с поверхности речных водосборов, создавая условия для развития эрозии;

- рельеф и крутизна склонов.

В характеризуемом регионе наибольшая оврагоопасность при густоте оврагов более 0,8 км/км ${ }^{2}$ и их плотности более 0,5 шт/км² отмечается в Белгородской, Воронежской, Курской, Липецкой, Орловской областях. Тамбовская область характеризуется малой оврагоопасностью.

В Центрально-Черноземном регионе рельефообразующие породы представлены, в основном, карбонатами, в связи с чем на данной территории хорошо развиты карстовые процессы (рис. 3). При этом здесь обычно наблюдается так называемый покрытый карст, образование которого связано с верхнедевон- скими известняками, а также мелом и мергелями верхнемелового возраста, покрытыми песками и глинами четвертичного возраста и почвенно-растительным покровом.

Опасность развития карстовых процессов отмечается в Орловской области и на северо-западе Липецкой, где пораженность территории карстом превышает $25 \%$, скорость карстовой денудации - до $5 \mathrm{~m}^{3} / \mathrm{m}^{2}$, диаметр поверхности карстовых форм достигает 30 м, местами - до 150 м, а риск провалов составляет: один провал на 1 км $^{2}$ в 10 лет. В этом районе отмечается разрушение промышленных и гражданских сооружений, повреждение коммуникаций.

В районе распространения верхнедевонских известняков выявлено около 1000 карстовых форм рельефа. Среди них наиболее распространены карстовые воронки, которые часто покрыты лесом и кустарником, а также заросли разнотравно-злаковой растительности. Здесь также имеет место значительное развитие циркумментов-форм эколого-геодинамической активности территории.

Карстовым процессам особенно подвержены балки и придолинные склоны рек Дон, Воргол, Большая Чернава, Сосна, Вязелка, Еманча, Красивая Меча и Пальна, где насчитывается до 20-30 карстовых форм

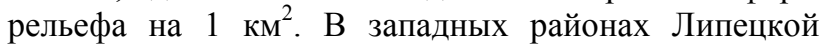


Характеристика природных процессов на водосборах средних и мальх рек Центрально-Черноземного региона

\begin{tabular}{|c|c|c|}
\hline Районы & Водосборы малых и средних рек & Природные процессы \\
\hline I & $\begin{array}{l}\text { Вытебень, Нугрь, Ока, Цон, Рыбница, Зуша, Неручь, Семенек, } \\
\text { Любовша, Труды, Большая Чернава, Сосна, Олым, Бол, Верейка, } \\
\text { Вязовка, Красивая Меча, Снова, Ведуга, Девица }\end{array}$ & $\begin{array}{l}\text { Овражная эрозия (1), Плоскостной смыв } \\
\text { (2), карст (1) оползни (2), Просадка } \\
\text { грунтов (2) }\end{array}$ \\
\hline II & Новля, Нерусса, Свапа & Овражная эрозия (2), плоскостной смыв (2) \\
\hline III & Усожа, Тускарь & $\begin{array}{l}\text { Овражная эрозия (3), плоскостной смыв } \\
(2), \text { карст (3), просадка грунтов (2) }\end{array}$ \\
\hline IV & Сейм, Амонька, Клевень & $\begin{array}{l}\text { Овражная эрозия (3), плоскостной смыв } \\
(2), \text { карст (3), просадка грунтов (2) }\end{array}$ \\
\hline $\mathrm{V}$ & Тим, Кшень & $\begin{array}{l}\text { Овражная эрозия (3), плоскостной смыв (1), } \\
\text { просадка грунтов (3) }\end{array}$ \\
\hline VI & $\begin{array}{l}\text { Илек, Суджа, Пена, Пселл, Ворксла, Харьков, Сев, Донец, Коро- } \\
\text { ча, Нежеголь, Оскол, Валуй, Айдар, Белая }\end{array}$ & $\begin{array}{l}\text { Овражная эрозия (1), плоскостной смыв } \\
(1), \text { карст (2), оползни (2), просадка } \\
\text { грунтов (3) }\end{array}$ \\
\hline VII & $\begin{array}{l}\text { Нижняя Девица, Потудань, Тихая Сосна, Усередец, Ольховатка, } \\
\text { Россошь, Черная Калитва, Богучар, Левая Богучарка }\end{array}$ & $\begin{array}{l}\text { Овражная эрозия (1), плоскостной смыв } \\
(1), \text { карст (2), оползни (1) }\end{array}$ \\
\hline VIII & $\begin{array}{l}\text { Чигла, Осередь, Гаврило, Толучеевка, Подгорная, Манина, } \\
\text { Криуша, Мамоновка }\end{array}$ & $\begin{array}{l}\text { Овражная эрозия (1), плоскостной смыв (2), } \\
\text { карст (3), оползни (3), просадка грунтов (1) }\end{array}$ \\
\hline IX & Дон, Репец, Ранова, Ягодная Ряса, Ряса, Иловай & $\begin{array}{l}\text { Овражная эрозия (3), плоскостной смыв (3), } \\
\text { карст (3) }\end{array}$ \\
\hline $\mathrm{X}$ & $\begin{array}{l}\text { Лесной Воронеж, Польный Воронеж, Воронеж, Матыра, Плави- } \\
\text { ца, Байгора, Усмань, Хава, Хворостань, Матыра, Битюг, Эртиль, } \\
\text { Курлак, Чигла, Цна, Кошма, Лесной Тамбов, Сухая Липовица, } \\
\text { Ира, Калаис, Мокрая Панда, Вяжля, Ворона, Шибряйка, Токай, } \\
\text { Елань, Савла, Карачан, Хопер }\end{array}$ & $\begin{array}{l}\text { Овражная эрозия (3), } \\
\text { плоскостной смыв (3), } \\
\text { просадка грунтов (2), } \\
\text { суффозия (1) }\end{array}$ \\
\hline
\end{tabular}

Примечание: I, II, III, IV, V, VI, VII, VIII, IX, X - районы с разными условиями развития природных процессов. В скобках цифрами показана степень интенсивности этих процессов: 1 - сильная; 2 - средняя; 3 - слабая и очень слабая.

области на днищах балок нередко карстовые воронки образуют длинные цепи взаимосвязанных карстовых ландшафтов.
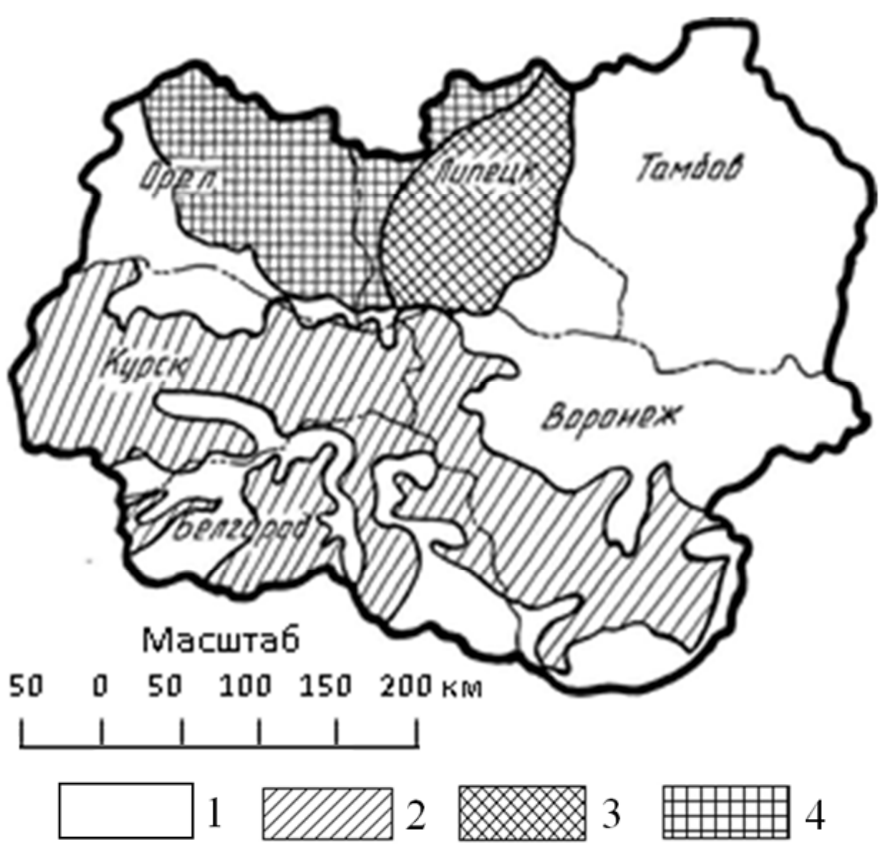

Puc. 3. Опасность возникновения карстовых процессов (общее количество карстовых форм). Условные обозначения: 1 - площади, на которых опасность, формируемая карстующимися породами, весьма незначительна; 2 - опасность незначительная; 3 - умеренная; 4 - сильная.
В Орловской и Липецкой областях карст является мощным ландшафтообразующим фактором и оказывает негативное воздействие на гидротехнические объекты, так как за счет фильтрации из строя выходят пруды и водохранилища. На правобережье реки Дон пораженность территории карстом достигает $50 \%$, в центре Липецкой области - $30 \%$, в бассейне реки Воронеж - $10 \%$.

Возможность возникновения кризисных экологических ситуаций, связанных с карстовыми процессами, в настоящее время отмечается также на западе и юге Воронежской области, в Курской и Белгородской областях, где рельефообразующими породами являются мела и мергели верхнемелового возраста, а пораженность территории составляет 10-25 \%. Здесь несколько ниже скорость карстовой денудации, меньше диаметр поверхности карстовых форм, а риск провалов составляет 0,5-1,0 на км² за 10 лет. Однако и в этих районах бывают случаи разрушения отдельных промышленных и гражданских сооружений, что негативно сказывается на уровне комфортности жизнедеятельности населения.

На Русской платформе лессовые просадочные грунты распространены к югу от $56^{\circ}$ сш., поэтому Центрально-Черноземный регион полностью входит в зону их распространения с опасностью возникновения кризисных экологических ситуаций. Здесь отмечаются две степени опасности просадок лессовых грунтов. 
Первая - опасная, которая встречается на северо-западе Орловской области, западе Курской, востоке и юге Воронежской области.

Вторая - умеренно опасная степень просадки грунтов, распространенная в Курской области на юге, Белгородской - пересекает (почти по центру) область с севера на юг, Воронежской занимает центральную часть и юго-восток.

Третья - с весьма незначительными локальными включениями просадочных грунтов, распространена на остальной части региона: восточных частях Орловской и Белгородской, северо-западной части Воронежской, Липецкой и Тамбовской областях (рис. 4).

При оценке условий возникновения экологических кризисных ситуаций в ЦентральноЧерноземном регионе необходимо учитывать количество и состояние русловых водоемов и прудов, построенных в балочной сети. Объем зарегулированного поверхностного стока прудами и водохранилищами составляет 1990 млн $\mathrm{m}^{3}$. Большинство прудов построено в балках, сложенных слабоводопроницаемыми породами, и имеет емкость до 500 тыс. м ${ }^{3}$. Крупные русловые водохранилища вмещают в себя более 100 млн м ${ }^{3}$ воды. Например, Воронежское водохранилище имеет емкость 204 млн. м ${ }^{3}$ [4].

Также, значительное количество плотин и гидроузлов на прудах и водохранилищах частично или полностью разрушены, что создает опасность для населенных пунктов, находящихся в зоне их влияния.

Центрально-Черноземный регион практически целиком входит в зону повышенной опасности переработки и разрушения берегов водохранилищ. Протя-

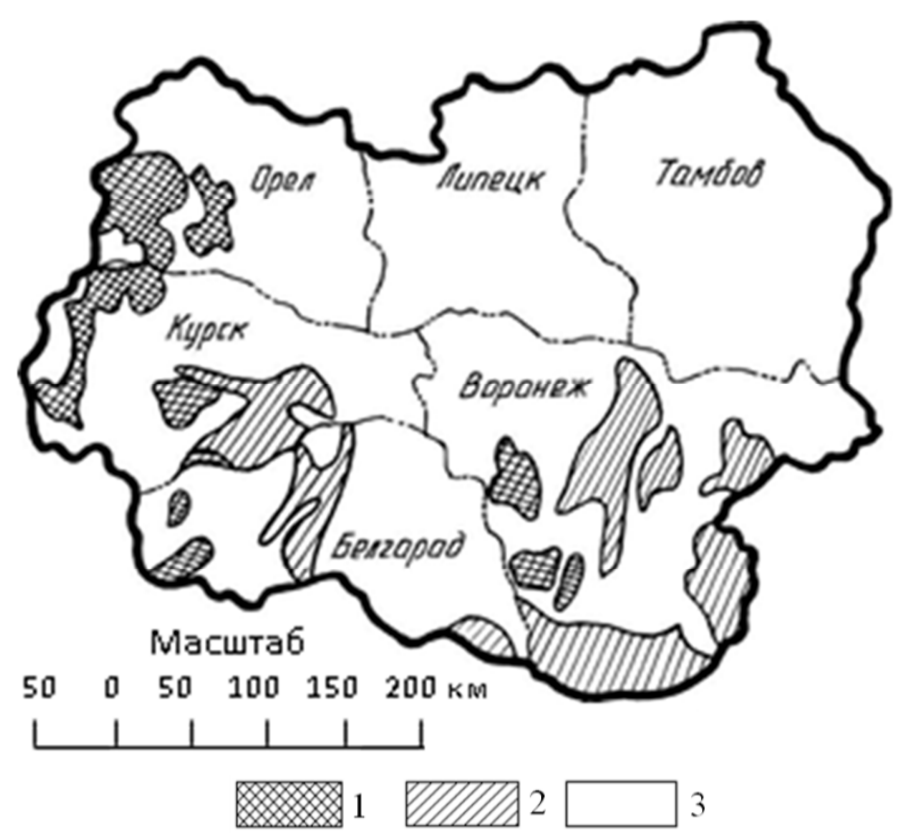

Puc. 4. Схема просадочности лессовых грунтов (км²). Условные обозначения: 1 - высокий уровень просадочности; 2 - средний уровень просадочности; 3 - низкий уровень просадочности.

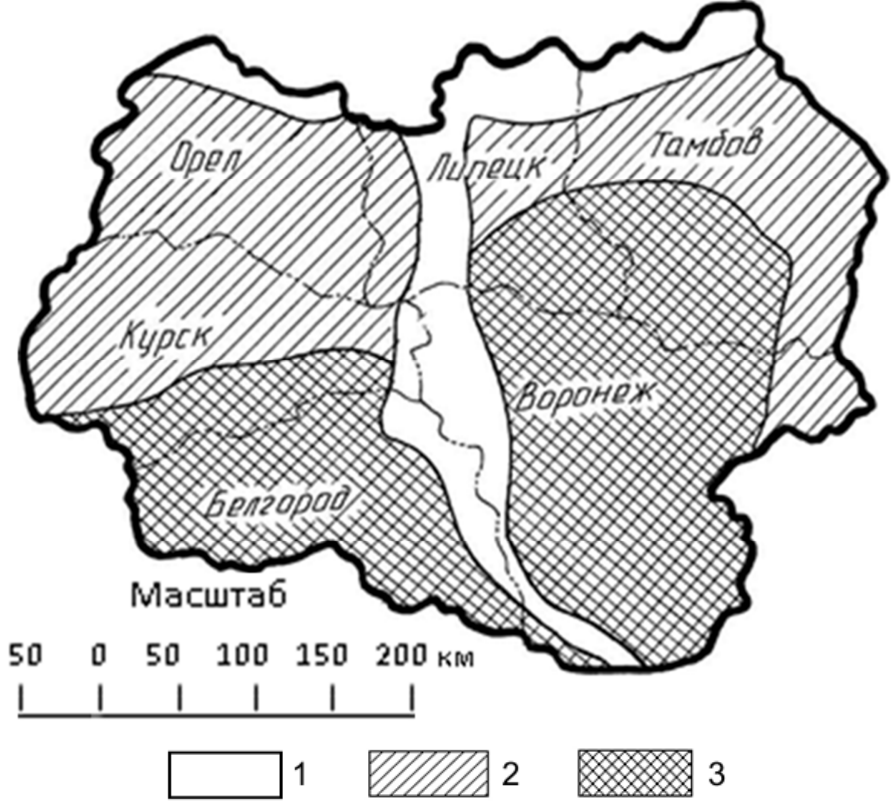

Puc. 5. Схема заиления русел малых рек. Условные обозначения: 1 - возможно среднее заиление; 2 - сильное; 3 - значительное заиление.

женность разрушаемых берегов в этом регионе составляет от 30 до $70 \%$, удельный объем переработки - от 12 до 70 тыс. м³/км/год, средняя скорость развития процессов по отдельным водохранилищам - более 3 м/год. Разрушение земель за 20 лет эксплуатации

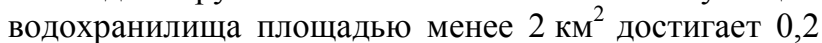
км$^{2}$. Разрушение побережий большей части периметра водохранилища влечет значительные экологический и экономический ущербы.

В характеризуемом регионе наблюдается сильное и полное заиление русел малых и средних рек, а также повсеместный размыв берегов рек в условиях свободного развития русловых деформаций (рис. 5).

Размыв берегов русла реки Дон происходит со скоростью порядка 2 м в год, механическое изменение русла наблюдается на 25-50 \% длины реки.

Таким образом, на территории Центрально-Черноземного региона Среднерусская и Калачская возвышенности относятся к наиболее оврагоопасным территориям, с сильной степенью опасности возникновения кризисных экологических ситуаций федерального и регионального уровней, а Окско-Донская низменность - имеет незначительную степень опасности. Плотность оврагов на опасных территориях сейчас составляет 2,1-5,0 шт./км²; прогнозная: 5,1-10,0 шт./км², а густота овражной сети: $0,5-1,3$ км/км²; прогнозная: 1,5-3,0 км/км². Средняя скорость роста оврагов - около двух метров в год. Овраги создают значительную расчлененность сельскохозяйственных угодий, что мешает работе сельскохозяйственных машин и выпасу скота, разру- 
шают экологические ниши природных экосистем; вызывают заиление прудов и речных русел; разрушение промышленных, жилых и строительных объектов.

Также на территории исследуемого региона значительно развиты карстовые процессы, наибольшая интенсивность которых отмечена в Орловской и, частично, Липецкой областях.

Опасная степень просадки лессовых пород встречается на северо-западе Орловской области, западе Курской, востоке и юге Воронежской области.

Центрально-черноземный регион почти полностью входит в зону повышенной опасности переработки и разрушения берегов водохранилищ.

В характеризуемом регионе наблюдается заиление русел малых и средних рек, которое оценивается как сильное и полное.

Эколого-геодинамическая характеристика Центрально-Черноземного региона должна стать одним из ведущих элементов методологии оценки и прогноза развития геоэкологических рисков территорий [7].

\section{Заключение}

- Проведенные исследования позволили выделить опасные эколого-геодинамические факторы, влияющие на возникновение кризисных экологических ситуаций: овражная эрозия, образование оползней, карст, просадка лессовых грунтов, переработка берегов, русловые процессы;

- Естественное развитие опасных экзогенных процессов в сочетании с накопленной и постоянно растущей антропогенной нагрузкой позволяет предположить повышение риска возникновения природных и техногенных кризисных экологических ситуаций.

- В результате проведенного эколого-геодинамического районирования по условиям возникновения кризисных экологических ситуаций нами была произведена дифференциация территории Центрально-Чернозёмного региона. Наибольшее количество природных опасностей локального уровня преобладает в Орловской и Тамбовской областях, муниципального - в Воронежской, Липецкой, Тамбовской и Белгородской, межмуниципального - в Курской, Липецкой и Воронежской.

- Проведенные исследования служат базой для

ФГБОУ ВО «Воронежский государственный технический университет». Овчинникова Татьяна Валентиновна, кандидат биологических наук, доцент

E-mail:tvo0104@mail.ru; Teл.: +7 (473)2713000

Ашихмина Татьяна Валентиновна, кандидат географических наук, доиент.E-mail:TV6234@yandex.ru

ФГБОУ ВО «Воронежский государственный университет».

Косинова Ирина Ивановна, д. г.-м. н., профессор, заведующий кафедрой экологической геологии

E-mail:kosinova777@yandex.ru; Тел.: +7 (473) 2208289 ФГБОУ ВО «Воронежский государственный педагогический университет». Смольянинов Владимир Митрофанович, доктор географических наук, профессор

E-mail: smolos-33@yandex.ru; Тел.: +7 (473) 2545017 Витебский государственный университет имени П. М. Машерова, р. Беларусь. Галкин Александр Николаевич, д. г.-м. н., проф.кафедрыгеографии.E-mail: galkin-alexandr@yandex.ru разработки и реализации стратегий и мер рационального природопользования территории ЦентральноЧерноземного региона.

\section{ЛИТЕРАТУРА}

1. Ashikhmina, T. V. Ecological safety - the main trends in the modern world / T. V. Ashikhmina, T. V. Ovchinnikiva, A. M. Ashikhmin // Safety of a person and society as a problem of social sciences and humanit: materials of the $\mathrm{V}$ international scientific conference on 5-6. Desember. - Prague: Vědeckovydavatelské centrum «Sociosféra-CZ», 2018. - P. 17-25.

2. Организация Объединенных Наций, Международная стратегия уменьшение опасности бедствий. Рамки для действий по осуществлению международной стратегии уменьшения опасности бедствий (МСУОБ) ОСНA/ISDR/2001/13. GE.0102322(R) 100901.120901. -25 c.

3. Смольянинов, В. М. Географические подходы при землеустроительном проектировании в регионах с интенсивным развитием природных и техногенных чрезвычайных ситуаций»: монография / В. М. Смольянинов, Т. В. Овчинникова. - Воронеж: Издательство «ИСТОКИ», 2010. - 230 с.

4. Адерихин, П. Г. Агрохимическая характеристика почв Центрально-Черноземной полосы / П. Г. Адерихин, Е. П. Тихова // Агрохимическая характеристика почв СССР. - М.: АН СССР, 1963. - C. 5-130.

5. Косинова, И. И. Особенности формирования донных отложений искусственных водоемов и методика их экологогеологической оценки / И. И. Косинова //В сборнике: Экологическая геология: теория, практика и региональные проблемы Материалы третьей Международной научно-практической конференции. Воронежский государственный университет и др.; под редакцией И. И. Косиновой, 2013. - С. 126-130.

6. Кузнецов, М. С. Эрозия и охрана почв: Учебник / М. С. Кузнецов, Г. П. Глазунов. - М.: Изд-во МГУ, 1996. -335 с.

7. Косинова, И. И. Теория и методология геоэкологических рисков / И. И. Косинова, Н. Р. Кустова // Вестник Воронеж. гос. ун-та. Сер.: Геология. - 2008. - № 2. - С. 189-197.

8. Куприенко, П. С. Оценка антропогенной нагрузки на окружающую природную среду Воронежской области / П. С. Куприенко, Т. В. Овчинникова, Т. В. Ашихмин // Ecological education and ecological culture of the population: materials of the $\mathrm{V}$ international scientific conferenceon, 25-26 February 2017. - Prague: Vědeckovydavatelské centrum «Sociosféra-CZ», 2017. - 173p. 9. Условия возникновения и особенности чрезвычайных ситуаций в Центрально-Черноземном регионе»: монография / Т. В. Овчинникова [и др.]. - Воронеж: Издательство «ИСТОКИ», 2007. $-230 \mathrm{c}$.

10. Шаги решения концепции «Безопасный регион» монография / Т. В. Овчинникова [и др.]. - Воронеж: Издательство «Цифровая полиграфия», 2018. - 334 с.

Voronezh State Technical University

Ovchinnikova T. V., Candidate of Biological Sciences, Associate Professor.E-mail: tvo0104@mail.ru; Tel.: +7 (473) 2713000 Ashikhmina T. V., Candidate of geographical Sciences, Associate Professor.E-mail:TV6234@yandex.ru

Voronezh State University

Kosinova I. I., Doctor of Geological and Mineralogical Sciences, Professor, Head of Environmental Geology Department,

E-mail:kosinova777@yandex.ru; Teл.:+7 (473)2208289

Voronezh State Pedagogical University

Smolyaninov V.M., Doctor of geographical Sciences, Professor

E-mail: smolos-33@yandex.ru; Тел.: +7 (473) 2545017

Vitebsk State University named after p. m. Masherov, Belarus Galkin A. N., Doctor of Geological and Mineralogical Sciences, Professor.E-mail: galkin-alexandr@yandex.ru 